\title{
5. Coral Bell and Her Mark on Strategic Studies
}

\author{
Robert O'Neill
}

Coral Bell's death on 26 September 2012 has taken from our field one of Australia's most able specialists in strategic studies. This loss is felt both nationally and internationally by all who knew her and studied her works, not least because she remained intellectually active right until her passing at the age of eightynine. Her writing was clearly focused, she was interested in some of the most important international problems of her lifetime, and she had great gifts of wit and sparkle which have illuminated her publications over a fifty year period.

I first came to know Coral personally in the early 1970s, when she held a chair at the University of Sussex. Thereafter, through our membership of the International Institute for Strategic Studies (IISS), we had more regular contact, enabling me to see how highly regarded she was in Western Europe and North America. She became well known for her work on American foreign policy in the 1940s and 1950s, the nuclear weapons contest of the Cold War, and crisis management. I began to read her works in 1962, as a result of the publication of her second book, Negotiation from Strength. ${ }^{1}$ This volume was a wonderfully powerful and illuminating analysis of US policy in the late 1940s and 1950s, and had much to teach any new scholar (such as myself) on the nature of the Cold War in the nuclear era. I first saw it soon after its publication in 1962, when browsing the shelves of Blackwells' Bookshop in Oxford during my time as a student there. Very soon I purchased my own copy. I also took heart from the discovery that an Australian scholar could achieve such a breakthrough on the home territory of many of the great names of our discipline.

Coral had come to adulthood during the Second World War, and knew from her own experience just how much was at stake when great powers went to war with modern weapons. The consequences of war were, of course, even more horrifying to think about in the 1950s when the opposing sides could use nuclear weapons on each other. Coral had become interested in weapons technology as a result of war work in the National Physics Laboratory in Sydney on de-magnetizing steel-hulled ships, known then as degaussing. She never forgot the experience of learning about the atomic bombing of Japan in 1945, and her fertile brain was able to imagine how the world would fare in an era

1 Coral Bell, Negotiation from Strength: A Study in the Politics of Power, Chatto \& Windus, London, 1962, and Alfred A. Knopf, New York, 1963. 
where these weapons had proliferated and become even more destructive than those of 1945. This experience coloured the whole of her intellectual life, as is made clear by the title of her unpublished memoir, 'A Preoccupation with Armageddon'.

Coral was fascinated by the importance of the challenges posed, and had the intellect and confidence to get to grips with them. In 1944 she opted for a career in diplomacy because she thought that it was the most interesting work available. She wanted to understand the nature of the problems presented by modern warfare, and have some influence on the development of national and international policies to deal with them. Initially the Department of External Affairs in Canberra gave her the stimulating assignment of analysing the Baruch Plan for the international control of nuclear weapons. However, as her conclusion to that study was that the Russians would kill it through refusal to participate, there did not seem much point in her continuing with that study. She moved on to study the Arab-Israeli problem, and then the Southeast Asian region. Given that she was also reading a mass of highly secret cables from London and Washington in those early years of the Cold War, she received an excellent grounding both in the complexities of these major international problems, and in the realities of power politics at the international level.

After six years, having seen that a diplomat, particularly a woman, was likely to be assigned minor responsibilities and a life of social tedium on the round of National Day receptions, cocktail parties and 'dips dinners', she decided in 1951 to pursue her professional interests through becoming an independent scholar of international relations. She had a lot to contribute to the policymaking deliberations of the Australian government, but not many people in the Department of External Affairs were prepared to listen to a young woman on these issues. She had not been impressed by being posted to Wellington. At least she had fared better in being admitted to Dr Evatt's Department of External Affairs than had Jill Ker Conway, later to be a celebrated author and academic, who in the late 1950s was turned down flat when she applied for an entry-level post in the same Department.

Coral knew how small was the group of Australian academics who specialised in international relations. Also she had a low opinion of several of them, so she decided to work in a wider arena, namely London, where she won a place as a graduate student at the London School of Economics (LSE). She arrived in time to experience the sea-change which occurred after Michael J Oakeshott replaced the deceased Harold Laski as Professor of Political Science. The Marxist-inspired values of Laski were replaced by a much more conservative flow of ideas and challenges from Oakeshott, which ran in parallel with other changes in dominant modes of thinking in other parts of the world. The Soviet Union in particular became much more the object of criticism and suspicion, 
and governments in many countries such as Britain and Australia turned from what Coral called a Fabian outlook towards something much more in harmony with the philosophies that Oakeshott espoused.

While she was at the LSE, Coral was strongly influenced by Martin Wight, whom she described as 'not only a friend and a colleague but the chief intellectual influence of my entire life'. She was also assisted by Geoffrey Goodwin who introduced her to the Royal Institute of International Affairs (RIIA, Chatham House). There she was appointed as rapporteur of a group of scholars who were assisting Goodwin in the production of a book on Britain and the United Nations. ${ }^{2}$ Having worked in the United Nations Division of the Department of External Affairs in Canberra, Coral was well placed to make her own contributions to the group's thinking.

Soon afterwards she was appointed to assist Arnold Joseph Toynbee, Director of Studies at Chatham House, with the preparation of the Survey of International Affairs for 1954. ${ }^{3}$ Toynbee had written the earlier volumes in this series himself, but after more than twenty years of such labours, he was keen to delegate the task to a younger person. After some initial testing of Coral's abilities, he selected her for the post. This appointment was important for Coral not only in terms of building her academic reputation but also as a necessary source of income while she was still a graduate student at the LSE. She distinguished herself in this, her first book, by lessening the usual emphasis of the series on European affairs and giving prominent treatment both to the French defeat at Dien Bien Phu, and to nuclear weapons and their implications for international politics.

Coral's post as rapporteur for the project on Britain and the United Nations gave her the opportunity to meet and get to know several rising British political and academic leaders, especially three who were to play major roles in founding the International Institute for Strategic Studies (IISS) in 1958: Denis Healey MP, Michael Howard and Alastair Buchan. She was impressed both by the intensity of their experience in the Second World War and by their belief that war had become too dangerous to be an acceptable way of solving international problems.

Her results at the LSE and Chatham House earned her the strength of reputation to compete successfully for a Lectureship in International Relations at the University of Manchester in 1956. This post gave her the opportunity to develop her ideas on how the US was managing the Cold War, and her doctoral thesis formed the basis of her second book, Negotiation From Strength. The central theme of her research became the development of Western policies which would maintain essential Western interests and values, while avoiding

2 See Geoffrey L Goodwin, Britain and the United Nations, National Studies on International Organization, Manhattan Publishing Company, New York, 1957.

3 See Coral Bell, Survey of International Affairs for 1954, Oxford University Press, London, 1956. 
the need to go to war with nuclear weapons. To understand the bases of current Western security policies, she saw that it was necessary to undertake research and interviews in the United States. With the strong support of her department head at Manchester, Professor WJM ('Bill') Mackenzie, she won a Rockefeller Fellowship which gave her the necessary financial support, and some useful contacts, for her to spend several months in the United States in 1959. Coral certainly did not lack intellectual ambition and confidence, and by the time that she was aged thirty-six she was interviewing former senior US officials from Secretary of State Dean Acheson downwards, and she was applying her mind and powers of expression to the critical analysis of the most central elements of Western strategy in the early years of the Cold War.

One of the targets of her criticisms was the CIA-inspired operation to topple the Iranian nationalist leader, Dr Mossadegh, and put the young Shah back on his throne. Coral saw in this move a major encouragement for Islamic fundamentalists which would result in the overthrow of the Shah and the series of Ayatollah-led governments that Iran has had since then. She had become wary of United States administrations which exerted their economic and military power to re-shape other national societies in accordance with US preferences. This line of thought led her to oppose US military involvement in Vietnam. During her travels in the United States she became increasingly aware of the internal debate on policy towards Southeast Asia. Having administered Australian policies for Southeast Asia in the late 1940s, she knew a lot about that region and its conflicts, and could see how counter-productive a major American military effort there might be. On the other hand, as she examined US policy during the Korean War, she perceptively noted that the main American influence in that conflict was diplomatic rather than military. The military pressure applied by the Truman administration was to strengthen the UN Command's negotiating position rather than to achieve a military victory on the Korean Peninsula. At least the United States had learned from its Korean experience not to take Chinese passivity for granted in Vietnam. But this awareness did not enable the US to find a way to close off the vital supply links between China and North Vietnam on the 1960s. The two main rivals of the Korean War therefore faced each other for over a decade in Vietnam, while the North Vietnamese slowly built up their strength just as American public support for the conflict was declining.

During her time in the US in 1959, Coral also came to focus on nuclear weapons policy, and had the good fortune to interview Robert Oppenheimer, reputed to be 'the father of the atomic bomb' (with Enrico Fermi) and by then Director of the Institute of Advanced Studies at Princeton. Oppenheimer, who had been the object of political controversy in the United States for several years on account of his communist links in the 1930s, had been deprived of political power and influence, so the opportunity to be questioned rigorously by a young 
political scientist must have been stimulating for him, and he opened up, in the unguarded way that some senior US officials do when out of office. Oppenheimer was willing to discuss secret matters with Coral, and alerted her to the existence of the memorandum NSC-68, which was one of the main guidelines of American policy through the Cold War. Although she was not able to see a copy of this key policy statement on that visit, she soon learned enough about it through other interviews to have a reasonably detailed knowledge of its contents. Coral was impressed by its espousal of George Kennan's policy of containment of the Soviet Union, as she was by the friendship which existed between Kennan and Oppenheimer. She was learning at first hand of the fascinating debates in Washington on nuclear weapons policy and US-Soviet relations which were such a strong feature of the 1950s and 1960s. This was an excellent foundation for one of her main life-long fields of interest, as well as equipping her for a role in the debates on nuclear weapons policy which were the central element in the work of the International Institute for Strategic Studies in the 1950s and 1960s. It was all very stimulating for her research and writing on the policies of the great powers, and with this reserve of knowledge on which to draw, she was able to produce work at a high international standard and further enhance her rapidly growing reputation.

By the early 1960s Coral felt the pull of her homeland and successfully sought a post as a Senior Lecturer in Government at the University of Sydney, which she held from 1961 to 1965. She found the experience of being back in the midst of the Australian foreign policy debate disappointing, and even alienating. Australian foreign policy had been stuck in an orthodox conservative rut for over a decade, and while Coral was relatively conservative herself, she thought that the growing tensions between the United States and North Vietnam should be wound down and certainly not exploited as a justification for the United States and Australia to go to war in Vietnam. She became caught up in the discussions on Vietnam organised in Sydney by Dick Krygier and Owen Harries, two of the central figures in the production of Quadrant, then as now, a conservative journal which focused on culture and literature, but also covered foreign policy issues, among others. ${ }^{4}$ Coral's perspective was that of an opponent of Soviet and Chinese attempts to gain more influence in world affairs, but who saw participation in a war in Vietnam as more likely to serve communist interests than those of the West. In putting forward these views, she had been greatly reinforced by her personal experience of the debate in the United States of the late 1950s and early 1960s.

4 See Coral Bell, 'The State of the Discipline: I.R.', Quadrant, vol. 12, no. 1, January-February 1968, pp. 79-84.; 'The Winning of the Cold War', Quadrant, vol. 34, no. 3, March 1990, pp. 13-24; 'The Future of Power in World Affairs', Quadrant, vol. 39, no. 9, September 1995, pp. 49-56; 'A Hard and Bitter Peace: The Cold War in Retrospect', Quadrant, vol. 40, no. 3, March 1996, pp. 18-22; 'World Out of Balance?', Quadrant, vol. 41, no. 7-8, 1997, pp. 35-40; and 'Washington and its Allies', Quadrant, vol. 41, no. 1-2, 1997, pp. 19-24. 
The debate in Australia on Vietnam in the early 1960s had been influenced strongly by recent experience of The Malayan Emergency. It was further reinforced towards anti-communism by growing tensions with Indonesia which were to result in Australia's deployment of forces in Borneo to resist Soekarno's confrontation of Malaysia (1964-1965). Coral, having been out of Australia for most of the 1950s, saw things differently and did not want to plunge into a series of controversies with other experts who, on the whole, had similar views on the conduct of East-West relations in the broad, if not on Vietnam. As far as the Australian government was concerned, Menzies was very much in charge of foreign policy in the early 1960s. As she herself has written, 'Much more important, Australia seemed suddenly to be in a lonely place, internationally, diplomatically and strategically'. Coral's disapproval of government foreign policy views was fully mirrored by her low opinion of Labor leaders' views, especially those of Arthur Calwell, despite his opposition to the Vietnam War. Coral saw little hope of making an impression in policy-making circles with her views, so she turned her gaze back to the academic scene in Britain.

There she was soon successful, being offered a Readership in International Relations at the LSE, a senior post at one of the most prominent centres for the study of international relations in the world at that time. She enjoyed returning to the broader work in which she had been so heavily involved in the 1950s, and did well. She added to her reputation through her work for the IISS and Chatham House on nuclear weapons, American and NATO policies, and Western relations with the Soviet Union. In 1972 she was appointed to a Professorship at the University of Sussex, there working with her much-esteemed former colleague, Martin Wight.

After twelve years in Britain, Coral again felt the pull of home, drawn especially by the strength of the International Relations Department at The Australian National University (ANU) in Canberra. She had known JDB ('Bruce') Miller, the Head of the Department, in Britain in the 1950s, and while Coral was at the University of Sydney in the early 1960s, Bruce had relocated to ANU from the University of Leicester. Coral, however, in the 1960s regarded Canberra with no special favour, and preferred to return to London in 1965.

Much as she liked working in good British universities and living in London, Coral became increasingly uncomfortable at the growth of radicalism among the student body in the UK. Although she had remained opposed to the Vietnam War, her opinions on other major issues of the Cold War were on the conservative side, and she soon came under attack for some of her more 'realist' views of international affairs. Also administrative pressures were eroding the very collegial atmosphere that senior common room members in the UK enjoyed in the years before the Thatcher era. Thus, for several reasons, ANU seemed to 
Coral in 1977 to be a better place in which to work than the UK. Also Canberra, no longer dominated by Menzies and his pro-British attitudes, seemed to Coral to be a much more interesting place to work in.

Another of the reasons for the change in Coral's attitudes towards Canberra had been Hedley Bull's work there from 1967 to 1977. They had known each other in London in the 1950s and 1960s, and had similar interests in power politics. Although Hedley had come and gone again before Coral made her move to Canberra in 1977, he had shown an ambitious scholar like Coral what could be achieved from ANU. Bruce had been keen to bring Coral to a senior, tenured post in the Department for some time, and she was appointed as a Senior Fellow in 1977. She worked in that capacity for the next eleven years until her formal retirement in 1988.

The ideological opposition that she had encountered was particularly galling to Coral because from the early 1960s she had been a profound sceptic about the ultimate worth of American and allied participation in the Vietnam War. She had studied the debate at first hand inside the United States in the late 1950s and early 1960s, and although the Vietnam War did not become a central part of her work, she did not fail to let everyone know that she was opposed to it. Having had to go to Vietnam myself as a member of the Australian Army, I did not share all her views on the conflict, particularly her willingness to allow the South Vietnamese to be ruled by a fairly dictatorial regime based in the North. But having seen how much of the US Army failed to learn from painful experience in Vietnam, it was not difficult for me to see the wisdom of Coral's overall evaluation as to how the war was likely to end. I learned a lot from her.

In 1977, when Hedley Bull left ANU for the Montague Burton Chair of International Relations at Oxford, a senior vacancy was thereby created in the ANU International Relations Department. Unfortunately it was not Hedley's chair, for ANU snaffled it back and left only a Senior Fellowship to be filled. But that was still an attractive position in terms of emoluments, research support and standing, and Coral was an obvious candidate. She was duly appointed and joined the Department for the following eleven years until she reached retiring age.

Coral was an expert organiser of interesting seminar series. She would build a series largely out of existing resources in terms of presenters, connected thematically to give PhD scholars and faculty members alike an opportunity to present their recent work. She was also an excellent seminar chair, keeping discussion focused on the most important issues, and moving along at a good speed. She could briskly terminate any self-indulgent monologues from other participants. Her seminar series continued to be in demand well after her official retirement, so she was appointed an Adjunct Fellow and continued to run discussions until well into the 1990s. She also maintained her international 
contacts by travelling, especially to the annual conferences of the International Institute for Strategic Studies, which gave me a good opportunity to catch up regularly with her views and activities in the post-1982 period. I well remember the warmth of Coral's greetings and how much I enjoyed her thoughts on what were likely to be the new issues to emerge in the forthcoming debates of this world-wide body of policy shapers, scholars and journalists.

During Coral's first five years at ANU, when I was the Head of the Strategic and Defence Studies Centre, she was a wise and supportive counsel, especially in university-political matters. She was a regular attendee at Centre seminars, discussion groups and conferences. One set of insights for which I shall always be grateful to her was her characterisation of the NATO alliance as 'always in disarray'. This appraisal has been truer over many years than many observers realise or will admit to. For most of its life in the twentieth century, NATO was good for one thing only: supporting the Germans against any Soviet conventional attack through Central or Northern Europe. For the rest it seemed to be largely an arena for complaints against the United States and debate about the need for making any commitment outside the 'NATO area'. For Australia there were some positive and some negative lessons from this experience of handling relations with the United States. For myself, as Director and then Chairman of the IISS, the wisdom of Coral's words on NATO was continually borne out through the 1980s and 1990s. I never forgot her characterisation.

For most of her professional academic life, Coral was primarily concerned with studying and analysing American methods of managing the alliance. While this focus had led her to oppose the war in Vietnam, she thought better of US policies in the field of arms control - a policy area that she held to be a very important way of stabilising the East-West relationship. Although Coral was regarded as a 'conservative realist', and even used that term about herself, she had her own very independent and well founded view of US policies and capabilities. Hence, like Owen Harries, another 'conservative realist', she was a strong critic of George W Bush's foreign and military policies. She could see how counterproductive Bush's illegal invasion of Iraq would be, and she became increasingly clear in her own mind that the US had lost 'sole superpower' status and was moving towards a world order in which power would be shared by several major states. Right until the last, Coral remained committed to this complex view of the world. She was certainly not a conservative in the American sense of the term.

I refer those interested in a more detailed summation of how Coral's thinking moved with, or ahead of, the times to an article she published in American Review, the journal of the United States Studies Centre of the University of 
Sydney in 2009. ${ }^{5}$ It is a forward-looking analysis of what President Obama had to do over the coming seven years of the two presidential terms that she gave him. While not an uncritical admirer of Barack Obama, Coral praised him for recognising that the world had undergone a 'profound, irreversible redistribution of power ... that actually has far more to do with China and India than with the Europeans'. Obama's increased emphasis on the G20 was very much to his credit, and accorded with the real distribution of power in the world.

Coral developed this forward looking analysis on the basis of the historical record, particularly the experience of Europe in the nineteenth century, when its disputes were dealt with through the Concert of Powers mechanism, which had been set up to restore stability at the end of the Napoleonic Wars. With an experienced eye for the strengths and limitations of diplomacy, Coral advocated a broadening of this well-founded concept in order to help resolve the international problems of the twenty-first century. We are now five years further into the seven about which Coral was writing in 2009, and so far, so good. The world still has many problem areas and issues, from the proliferation of nuclear weapons to political instability within several key Islamic countries in the Middle East and South and Southeast Asia.

Her support for Obama's basic outlook on world affairs reveals a significant degree of change from the attitudes of a 'conservative realist' of the Cold War era who placed high value on authority and cohesion within alliance systems, nuclear weapons and arms control agreements. The causes of this change were two-fold: the rise of other powers within the international system, and the counter-productiveness of the policies of President George W Bush and his neocon advisers. She was aware of the growing fragility of the international system and many of its second-level players, and the increasing leverage of non-state actors, who were anathema to someone who had learned about international relations from the perspective of a member of a well-run national diplomatic corps.

Coral brought together a capacity for anticipating political and strategic changes in the world, and a historical knowledge which enabled her to put forward ways and means for implementing new policies to deal with these changes and keep the world on an even keel. She was primarily interested in improving policy rather than in international relations theory. For the whole of her professional life she wrote clearly and comprehensibly on the major policy issues of the time - a demanding field in which to operate because there was so much competition. But she was better than most of the other analysts that she was up against. When she came to annual conferences of the International Institute for Strategic

5 Coral Bell, 'Seven Years to Get it Right', American Review, November 2009, http://americanreviewmag. com/stories/Seven-years-to-get-it-right, (accessed 11 November 2013). 
Studies, she could always command a good audience of other participants, both in the formal sessions of the conference and the informal, over meals, coffee or cocktails. She had remarkable longevity as an expert analyst, serving as a model for us all of how to enjoy one's senior years without overdoing the commitment to professional work, while still maintaining a clearly visible position in the international panoply of distinguished scholars.

Her analytical legacy is a view of a world where US power and influence have been eroded through poorly thought-out policies and lack of understanding of the United States' own weaknesses in the first decade of this century. At the same time the capacities of China, Europe, Russia, and India have grown and they need to be taken more into account by the strongest power in the world, if it is not to be displaced by one or more of the others. For some, including myself, this view is a little too neat. It understates the likely influence of subnational groups, running to perhaps a few hundred persons each, some armed with weapons of mass destruction, and composed of young people willing to give their lives to kill Westerners. But Coral would respond to me that these subnational groups will lack the power of state governments and, with the right policies and military means, they could be ground down and eliminated individually. It was a merry discourse that we had in her apartment in Canberra on this topic three years ago. Who will be shown by events to be right?

Whatever our personal differences on matters of international policy, Coral was a splendid scholar and all of us who had the privilege of working with and learning from her, owe her a great debt for devotion to principles, intelligence, leadership and organising abilities. She had immense and accurate knowledge of international events and a warm nature. And she made an impressive climb to the high ground of international debate which is where most professional international relations analysts aspire to be. For all of us, regardless of nationality or gender, she has shown how to exert a wider impact in understanding our world. 
This text taken from Power and International Relations:

Essays in honour of Coral Bell, edited by Desmond Ball and Sheryn Lee, published 2014 by ANU Press, The Australian National University, Canberra, Australia. 